\title{
Indoor and Outdoor Nanoparticle Concentrations in an Urban Background Area in Northern Sweden: The NanoOffice Study
}

\author{
Hans Orru ${ }^{1,2}{ }^{*}$, Annika Hagenbjörk ${ }^{1}$ and Henrik Olstrup ${ }^{2}$ \\ 1 Section of Sustainable Health, Department of Public Health and Clinical Medicine, Faculty of Medicine, \\ Umeå University, 90187 Umeå, Sweden; annika.hagenbjork@umu.se \\ 2 Institute of Family Medicine and Public Health, Faculty of Medicine, University of Tartu, Ravila 19, \\ 50411 Tartu, Estonia; henrik.olstrup@ownit.nu \\ * Correspondence: Hans.Orru@umu.se; Tel.: +372-737-4203
}

Citation: Orru, H.; Hagenbjörk, A.; Olstrup, H. Indoor and Outdoor Nanoparticle Concentrations in an Urban Background Area in Northern Sweden: The NanoOffice Study. Environments 2021, 8, 75. https:// doi.org/10.3390/environments8080075

Academic Editors: Vânia Martins and Ki-Hyun Kim

Received: 21 May 2021

Accepted: 5 August 2021

Published: 9 August 2021

Publisher's Note: MDPI stays neutral with regard to jurisdictional claims in published maps and institutional affiliations.

Copyright: (c) 2021 by the authors. Licensee MDPI, Basel, Switzerland. This article is an open access article distributed under the terms and conditions of the Creative Commons Attribution (CC BY) license (https:/ / creativecommons.org/licenses/by/ $4.0 /)$.

\begin{abstract}
In recent years, nanoparticles (NPs) have received much attention due to their very small size, high penetration capacity, and high toxicity. In urban environments, combustion-formed nanoparticles (CFNPs) dominate in particle number concentrations (PNCs), and exposure to those particles constitutes a risk to human health. Even though fine particles $(<2.5 \mu \mathrm{m})$ are regularly monitored, information on NP concentrations, both indoors and outdoors, is still limited. In the NanoOffice study, concentrations of nanoparticles $(10-300 \mathrm{~nm})$ were measured both indoors and outdoors with a 5-min time resolution at twelve office buildings in Umeå. Measurements were taken during a one-week period in the heating season and a one-week period in the non-heating season. The measuring equipment SMPS 3938 was used for indoor measurements, and DISCmini was used for outdoor measurements. The NP concentrations were highest in offices close to a bus terminal and lowest in offices near a park. In addition, a temporal effect appeared, usually with higher concentrations of nanoparticles found during daytime in the urban background area, whereas considerably lower nanoparticle concentrations were often present during nighttime. Infiltration of nanoparticles from the outdoor air into the indoor air was also common. However, the indoor/outdoor ratios (I/O ratios) of NPs showed large variations between buildings, seasons, and time periods, with I/O ratios in the range of 0.06 to 0.59 . The reasons for high indoor infiltration rates could be NP emissions from adjacent outdoor sources. We could also see particle growth since the indoor NPs were, on average, almost twice as large as the NPs measured outdoors. Despite relatively low concentrations of NPs in the urban background air during nighttime, they could rise to very high daytime concentrations due to local sources, and those particles also infiltrated the indoor air.
\end{abstract}

Keywords: air pollution; air quality; indoor air; nanoparticles; health; toxicity

\section{Introduction}

Nanoparticles have recently received much attention due to their very small size and high penetration rate [1]. The nanoparticle itself is a submicroscopic particle that measures less than 100 nanometers $(\mathrm{nm})$ on at least one of its dimensions [2]. However, the term is sometimes also used for larger particles up to $500 \mathrm{~nm}[3,4]$. Some nanoparticles are known as ultrafine particles (UFPs), which are defined by their aerodynamic size of $<100 \mathrm{~nm}$ in all particle dimensions. Particles up to $300 \mathrm{~nm}$ are especially important since they are capable of diffusing rapidly in human airway mucus through the mucus pores $[5,6]$. Due to their small size and relatively large area in relation to volume, nanoparticles are believed to exert higher toxicity than larger particles [7].

Currently, there is no monitoring required or limit values set for nanoparticles or UFPs in ambient air. According to EURO 6, the only emission standard in terms of number of particles in vehicle exhaust is $6 \times 10^{11}$ particles per travelled $\mathrm{km}$, and the need to tighten this standard has been discussed [8]. 
The main source of ambient nanoparticles is different combustion processes that generate particulate matter ranging from micrometer-sized aggregates down to nanometersized particles [9]. Particles formed at high temperatures by gas-to-particle transitions are usually in nanometer size and are often referred to as combustion-formed nanoparticles (CFNPs) [10]. The main source of CFNPs in cities is vehicle exhaust [11,12]. However, nanoparticles can also be released from wear to brakes and tires as well as from rail/metro release of iron and other metals into the surrounding air [13-15]. Stationary sources of CFNPs include power plants, incinerators, and biomass burning [16,17].

In addition to CFNPs, there are a number of other anthropogenic and natural sources of nanoparticles. Engineered nanoparticles have also received increasing attention in recent years and are currently used extensively in different applications in electronics, cosmetics, agriculture, textile production, medicine, and many other industries and fields [18]. Indoor sources of nanoparticles include cooking, burning candles, and release from several types of construction materials [19]. In occupational environments, nanoparticles are also generated in combustion, in mechanical processes involving massive amounts of energy, as well as emissions from office equipment $[20,21]$. Since people spend $80-90 \%$ of their time indoors on average [22], exposure assessments focusing on indoor air are especially important. Since buildings are increasingly designed to be energy efficient and airtight, they require well-functioning ventilation systems that are maintained and used properly [23,24].

Nanoparticles are not exclusively anthropogenic but are also produced in nature through a variety of physical, chemical, and biological processes. More specifically, these particles originate from gas-solid nucleation in the atmosphere, chemical weathering of minerals, physical fragmentation, mineralization, redox reactions, photo-oxidation, and precipitation reactions [25]. During aerosol nucleation events, the concentration of nanoparticles can rise to 10,000 particles $\mathrm{cm}^{-3}$ or even higher [26]. Considering all those different sources, nanoparticles are to a greater or lesser extent always present in the air.

The health concern of nanoparticles comes mostly from their small size, which makes them capable of crossing several barriers in the body and passing into the circulatory and lymphatic systems, from which they can reach organs and tissues and damage biological structures and their functions [27]. It is also possible for nanoparticles to penetrate the brain and affect the central nervous system [28,29]. The toxicity of nanoparticles depends on several characteristics, including their size, shape, surface area and surface charge, agglomerate and aggregate formation, chemistry, hydrophilicity, and solubility properties [27]. Many studies indicate that at similar mass concentrations, nanometer-size particles are more harmful than micrometer-size particles [30,31].

The health effects associated with exposure to nanoparticles have been addressed in epidemiological studies. In a meta-analysis based on 85 original studies published between 1 January 2011 and 11 May 2017, the health effects associated with exposure to UFPs were reviewed. Epidemiological studies focusing on both short- and long-term health effects associated with exposure to UFPs were included. The most consistent associations were found for short-term effects on pulmonary inflammation, systemic inflammation, heart rate variability, and blood pressure. These effects were considered to be at least partly independent of other air pollutants [32]. In a prospective study of a Dutch cohort in which long-term exposure to a number of air pollutants, including particle number concentrations (PNCs), was analyzed, long-term exposure to PNCs was associated with an increased risk of cardiovascular diseases, whereas $\mathrm{PM}_{2.5}$ (particles less than 2.5 micrometers in diameter) was not associated with these outcomes [33].

In another meta-analysis in which a systematic review was performed to quantify the associations between particle components and daily mortality and hospital admissions in different cities, the effects associated with nanoparticles, calculated as particle number count (PNC), were positive but not significant in most cases [34]. The reason for these non-significant results might be attributed to the different origins of the nanoparticles in the cities involved in the studies or even to the different origin of nanoparticles on different days in a city [35]. The associations between exposure to particles in different size fractions 
and asthma symptoms have also been analyzed in four panel studies with asthma patients in Finland and Germany. A decrease in peak expiratory flow and an increase in daily symptoms and medication use were found for elevated daily nanoparticle concentrations and for elevated daily concentrations in $\mathrm{PM}_{2.5}$. In three out of these four panel studies, the associations were strongest for the nanoparticles [36].

Despite the potentially detrimental health effects caused by nanoparticles, the number of exposure assessments is still quite limited, especially for indoor environments. By analyzing the nanoparticle concentrations and characteristics indoors and the nanoparticle concentrations and characteristics in close connection outdoors, it is possible to get a better idea of which sources and which mechanisms control the indoor concentrations. The indoor/outdoor relationships (I/O relationships) of nanoparticle concentrations have been analyzed in a few studies. In general, the I/O ratios and correlation coefficients between indoor and outdoor concentrations have been shown to be high for nanoparticles [37-39]. Additionally, higher number concentrations of particles were measured in residences close to highways compared to the number concentrations measured in residences located farther away from highways [40], indicating the importance of nanoparticle infiltration.

The aim of this study was to measure the concentrations of nanoparticles in indoor and outdoor environments, to study the temporal and spatial variation in particle concentrations, to study the infiltration of ambient nanoparticles indoors, and to discuss indoor and outdoor sources of nanoparticles. In the NanoOffice study, we focused on office buildings, which constitute the workspace for a large occupational group in the European Union [41,42]. The wider scope of the NanoOffice study was to identify nanoparticle levels in offices and relate them to ambient air quality, technical characteristics of the buildings, and employees' perception of indoor air quality in northern Sweden.

\section{Materials and Methods}

The number concentration and size distribution of nanoparticles were measured during two one-week periods in the city of Umeå in northern Sweden. The measurement locations consisted of one outdoor location and 12 indoor locations in a total of 10 office buildings (Figure 1). These two one-week periods consisted of one week of measurements during the heating season and one week of measurements during the non-heating season. During these measurement periods, the windows were closed, and no employees were in the rooms where the measurements were performed due to noise annoyance caused by the measurement device. The office buildings were selected to include new, retrofitted and old buildings with various ventilation systems and different energy consumption. The office buildings were also chosen according to different distances from a busy street as the main sources of CFNPs. The busy street was defined as Petrus Laestadius street with a daily traffic flow of more than 700 buses, 100 trucks, and 2500 passenger cars [43].

At the same time as measurements were performed indoors in the selected office buildings, ambient air quality was monitored at a separate measurement point in the nearby outdoor environment. The study area with the locations of buildings and the outdoor measurement point is presented in Figure 1. Technical characteristics of the buildings are presented in Table 1.

The measurements were performed using the SMPS 3938 indoors and DISCmini outdoors. The SMPS 3938 (SMPS = Scanning Mobility Particle Sizer Spectrometer, TSI Inc., Shoreview, MN, USA) measures the size distribution of sub-micrometer particles. It combines electrical mobility sizing with single-particle counting to deliver nanoparticle concentrations in separate size channels. It consists primarily of an impactor to remove large particles (outside the size range of interest), a charger to neutralize the charges on particles, a controller to control flows and high-voltage, and a differential mobility analyzer (DMA) that separates particles based on their electrical mobility, as well as a condensation particle counter (CPC) placed downstream of the classifier that counts particles as they exit the DMA. The SMPS equipment is considered the "gold standard" for characterizing 
nanoparticles, and it has been widely used in studies in exposure assessments focusing on inhalation toxicology and industrial hygiene [44].

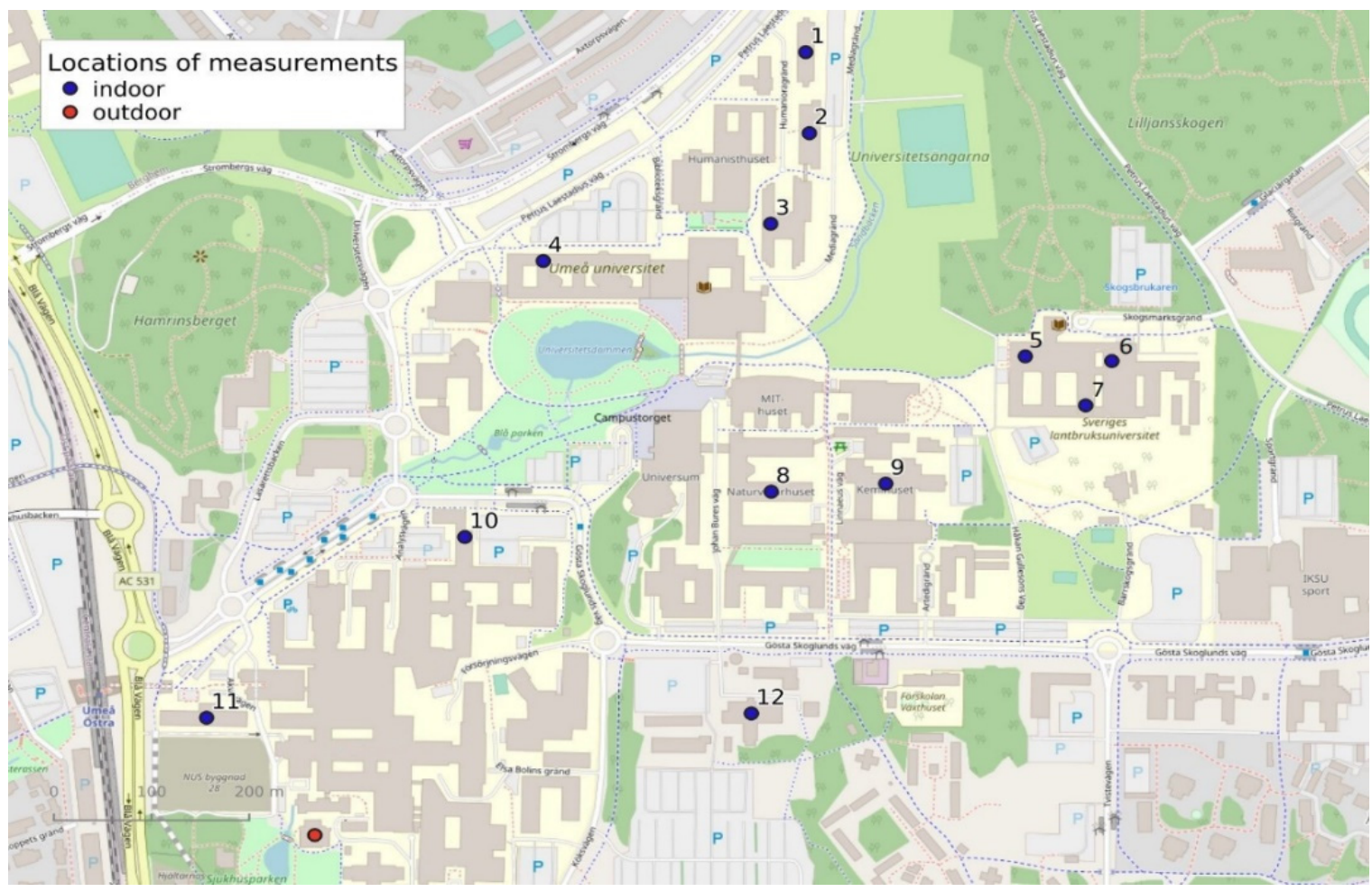

Figure 1. Study area with the locations of Buildings 1-12, where indoor measurements were carried out (blue circles). The outdoor measurements were carried out at the red circle. Basemap: (C) OpenStreetMap contributors.

Table 1. Technical characteristics of the buildings. Mechanical ventilation with heat recovery (MVHR) is used in all buildings.

\begin{tabular}{|c|c|c|c|c|c|}
\hline Building & $\begin{array}{c}\text { Year of } \\
\text { Construction }\end{array}$ & $\begin{array}{c}\text { Energy } \\
\text { Consumption } \\
\left(\mathrm{kWh} / \mathrm{m}^{2} / \text { year }\right)\end{array}$ & $\begin{array}{c}\text { Type of } \\
\text { Ventilation }\end{array}$ & Filter Class & $\begin{array}{c}\text { Distance from } \\
\text { Busy Street } \\
\text { (m) }\end{array}$ \\
\hline 1 & 2017 & $\mathrm{NA}^{1}$ & MVHR & $\mathrm{NA}^{1}$ & 850 \\
\hline 2 & 2002 & 118 & MVHR & F7 & 790 \\
\hline 3 & 1992 & 139 & MVHR & F7 & 700 \\
\hline 4 & 1968 & 106 & MVHR & F7 & 500 \\
\hline $5,6,7^{2}$ & 1978 & 154 & MVHR & F7 & $860,920,970$ \\
\hline 8 & 1966 & 121 & MVHR & F7 & 570 \\
\hline 9 & 1963 & 286 & MVHR & F7 & 680 \\
\hline 10 & 1960 & 270 & MVHR & M6 & 250 \\
\hline $11^{3}$ & 1935 & 160 & MVHR & F7 and F9 & 130 \\
\hline 12 & 1969 & 206 & MVHR & F7 & 550 \\
\hline
\end{tabular}

${ }^{1}$ Building 1 is security classified, and no detailed technical data are available (NA $=$ not available). ${ }^{2}$ Buildings 5 , 6 , and 7 refer to measurement points located in different parts of the same building where measurements were performed in different parts of the building. ${ }^{3}$ Completely renovated in 2014.

The SMPS was placed in offices near employees' regular workspaces (Figure 2). It was equipped with advanced aerosol neutralizer 3088 (TSI Inc.), DMA 3081 (TSI Inc.), and CPC 3788 (TSI Inc.). Altogether, 95 different size fractions were measured in the range between 10 and $300 \mathrm{~nm}$. The sampling interval was $5 \mathrm{~min}$. 


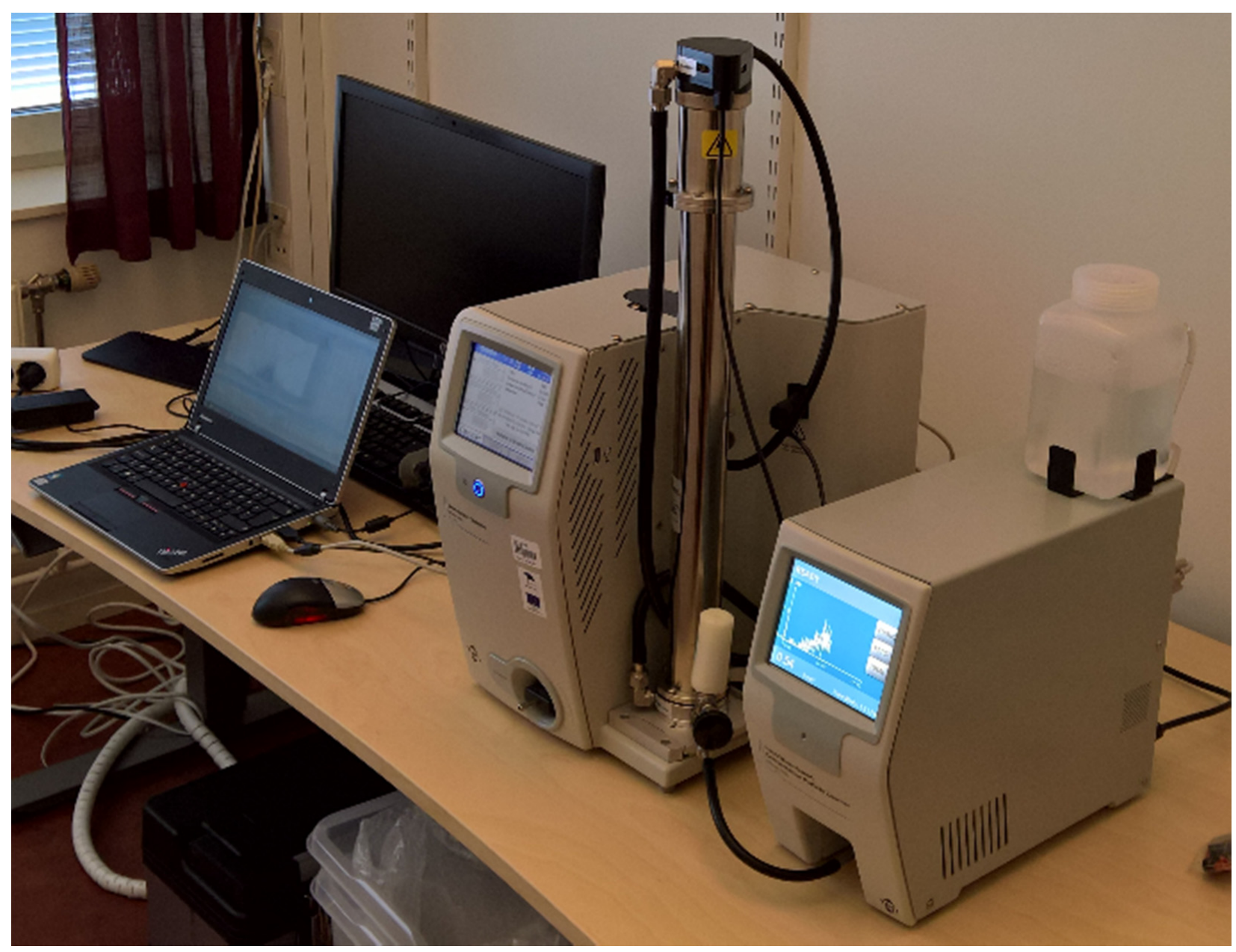

Figure 2. Measurement of nanoparticles indoors with SMPS 3938.

The DISCmini (Testo SE \& Co KGaA, Titisee-Neustadt, Germany) is a handheld nanoparticle counter used to measure number concentration and average diameter of nanoparticles. The measuring principle of the DISCmini is based on electrical charging of the particles. Positive air ions generated in a corona discharge are mixed with the aerosol. The charged particles are then detected in two stages by electrometers. The first detector stage utilizes a pile of steel grids; small particles will preferentially deposit on it by diffusion and are detected as an electrical current. The remaining particles end up in a second stage, the filter stage, and are also detected as an electrical current. The ratio of these two currents is a measure of the average particle size determined during the instrument calibration [45]. In the current study, the device was equipped with a heated probe (Figure 3). The probe was provided by ExIS AB, and it has been used by Grimm Inc. on the EDM 164 family of instruments. To measure the aerosol correctly at relative humidity levels above around $50 \%$, it must be 'dried'. A simpler solution is to use heated inlet solution, as has been suggested by ExIS AB, the distributor of DISCmini and Grimm instruments in Sweden [46]. 


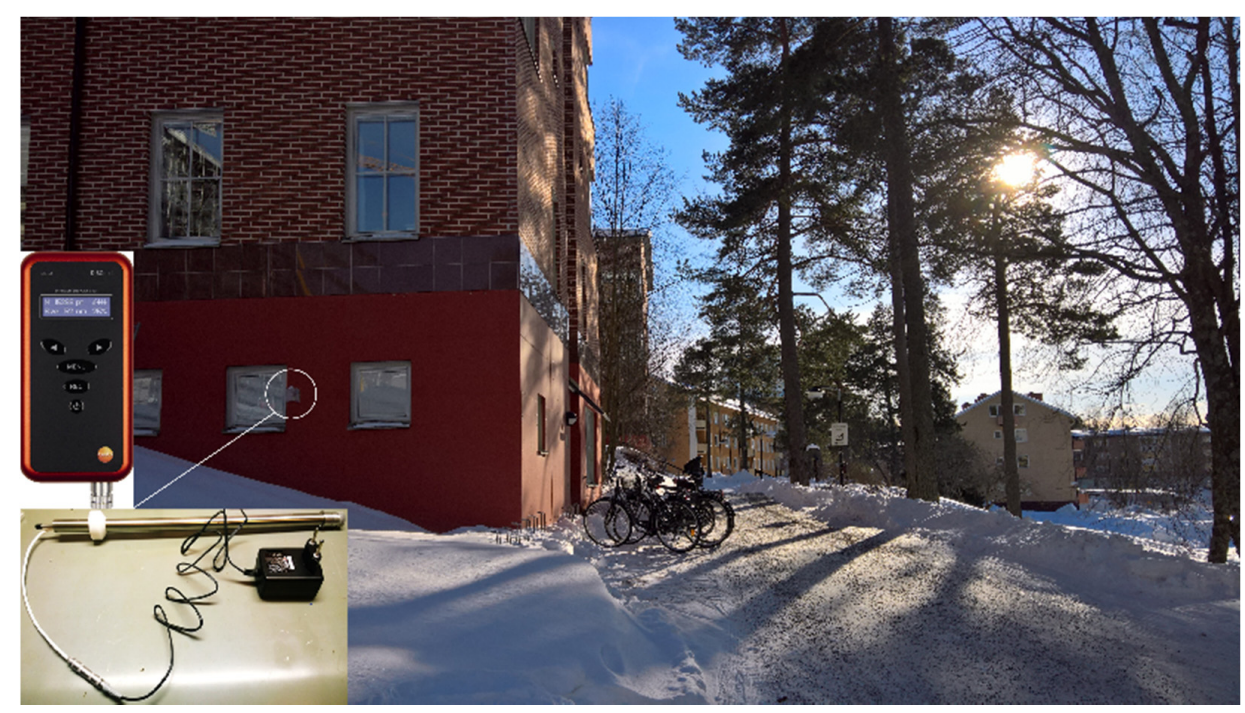

Figure 3. Measurement of nanoparticles outdoors with DISCmini. The photograph shows the measurement place, measuring device (placed indoors) and heated robe (put through the wall).

The heated inlet is approximately $0.5 \mathrm{~m}$ in length. It comprises a sampling head $(35 \mathrm{~mm})$, a heated pipe and connectors for the sample outlet and power. The stainless steel pipe in the heated pipe is polished, and since it is a straight pipe (from inlet head to instrument), the particle losses were expected to be low. The pipe is also electrically conductive, which avoids triboelectric effects. Heating of the pipe reduces thermophoretic losses (the heater cable increases a temperature of around $20^{\circ} \mathrm{C}$ ) [46].

The DISCmini has been used in several previous studies for measuring UFPs outdoors. For example, it was used in a study conducted in the city of Utrecht in the Netherlands in which UFPs were measured in front of fast-food restaurants in a largely pedestrian area in the city center [47]. The DISCmini equipment was also used in a study conducted in Montreal, Canada, in which spatiotemporal variations in outdoor UFP number concentrations and mean particle diameters were measured [48].

As two different devices were used, the measured size fractions of the SMPS were set to be similar to those of the DISCmini $(10-300 \mathrm{~nm})$. The correspondence between these two devices was tested by analyzing the correlation between the measurement results from the SMPS and DISCmini during parallel measurements in stationary conditions with real-life measurements indoors in Building 10 before the measurement campaigns. During the parallel measurements, the Pearson correlation coefficient was very high $(R=0.98)$, which is consistent with the results in previous studies by Meier et al. [49] and Ferrero et al. [50].

In the data analysis, the diurnal cycles and the temporal and spatial trends of the nanoparticle concentrations were analyzed. The correlation analysis was made with IBM SPSS statistics v26 [51].

\section{Results}

\section{Measurement Results}

Table 2 presents the average nanoparticle concentrations indoors and outdoors, the average size of the particles indoors and outdoors, the $\mathrm{I} / \mathrm{O}$ ratios according to

$$
\mathrm{I} / \mathrm{O} \text { ratio }=\frac{\text { Indoor number concentration }}{\text { Outdoor number concentration }}
$$

and the Pearson correlation coefficient between indoor and outdoor concentrations in 12 office buildings in an urban background area during a one-week measurement period in the heating and non-heating seasons. The average indoor concentrations varied between 182 and 3288 particles per $\mathrm{cm}^{3}$ and the average outdoor concentrations between 1208 and 6004 particles per $\mathrm{cm}^{3}$. The indoor nanoparticle concentrations in all buildings were lower 
in comparison with the outdoor concentrations measured at the same time. During the heating season, the average size of the nanoparticles indoors (arithmetic mean) was larger in comparison with the outdoor size in 11 out of the 12 cases; and during the non-heating season, the average size of the nanoparticles indoors was larger in comparison with the average size measured outdoors in all 12 cases. The correlation coefficients between indoor and outdoor concentrations showed large variations from 0.89 to -0.15 , but with generally low values (Table 2). Many different sources contributed to the nanoparticles measured indoors and outdoors. CFNPs originating from vehicle exhaust are an important outdoor source that can infiltrate the indoor air, but there are also a number of indoor sources that generate nanoparticles, such as cooking, smoking, burning candles, and using electrical appliances [52].

Table 2. Average number concentrations indoors and outdoors, average sizes of nanoparticles indoors and outdoors, I/O concentration ratios and correlations between indoor and outdoor concentrations in 12 office buildings in Umeå during the heating and the non-heating seasons. The buildings and their numbers are presented in Figure 1.

\begin{tabular}{|c|c|c|c|c|c|c|}
\hline \multirow{2}{*}{$\begin{array}{c}\text { Buildings } \\
1-12\end{array}$} & \multicolumn{2}{|c|}{$\begin{array}{c}\text { Average Number } \\
\text { Concentration (Particles } \\
\left.\text { per } \mathrm{cm}^{3}\right)\end{array}$} & \multicolumn{2}{|c|}{$\begin{array}{c}\text { Average Particle Size } \\
(\mathrm{nm})\end{array}$} & \multirow[t]{2}{*}{$\begin{array}{c}\text { I/O } \\
\text { Ratio }\end{array}$} & \multirow[t]{2}{*}{$\begin{array}{c}\text { Correlation } \\
\text { (Pearson) }\end{array}$} \\
\hline & Indoor & Outdoor & Indoor & Outdoor & & \\
\hline \multicolumn{7}{|c|}{ Heating season } \\
\hline 1 & 3288 & 5548 & 54 & 43 & 0.59 & -0.09 \\
\hline 2 & 316 & 4020 & 69 & 38 & 0.08 & 0.39 \\
\hline 3 & 911 & 3396 & 60 & 35 & 0.27 & 0.30 \\
\hline 4 & 182 & 1208 & 64 & 30 & 0.15 & 0.47 \\
\hline 5 & 253 & 3895 & 96 & 30 & 0.06 & 0.89 \\
\hline 6 & 459 & 5546 & 92 & 48 & 0.09 & -0.15 \\
\hline 7 & 398 & 4331 & 66 & 33 & 0.09 & 0.41 \\
\hline 8 & 396 & 4388 & 74 & 39 & 0.09 & 0.47 \\
\hline 9 & 575 & 2944 & 72 & 51 & 0.20 & 0.16 \\
\hline 10 & 1127 & 6004 & 69 & 51 & 0.19 & 0.73 \\
\hline 11 & 2211 & 5353 & 44 & 55 & 0.42 & -0.08 \\
\hline 12 & 465 & 4349 & 78 & 47 & 0.11 & 0.28 \\
\hline \multicolumn{7}{|c|}{ Non-heating season } \\
\hline 1 & 869 & 3572 & 73 & 34 & 0.24 & 0.07 \\
\hline 2 & 323 & 3929 & 86 & 45 & 0.08 & 0.19 \\
\hline 3 & 1170 & 3002 & 70 & 44 & 0.39 & 0.39 \\
\hline 4 & 649 & 3814 & 89 & 54 & 0.18 & -0.03 \\
\hline 5 & 726 & 3572 & 64 & 34 & 0.20 & -0.06 \\
\hline 6 & 1241 & 3244 & 59 & 35 & 0.38 & 0.16 \\
\hline 7 & 463 & 2537 & 69 & 34 & 0.18 & 0.34 \\
\hline 8 & 566 & 4332 & 88 & 43 & 0.13 & 0.04 \\
\hline 9 & 1139 & 3347 & 95 & 65 & 0.35 & 0.74 \\
\hline 10 & 879 & 2589 & 102 & 61 & 0.35 & 0.44 \\
\hline 11 & 575 & 3582 & 73 & 44 & 0.16 & 0.13 \\
\hline 12 & 598 & 2131 & 91 & 49 & 0.29 & 0.06 \\
\hline
\end{tabular}

In Table 3 the maximum and minimum nanoparticle concentrations are presented for the one-week measurement periods in Buildings 1-12 during the heating and the non-heating seasons. The maximum and minimum nanoparticle concentrations measured outdoors during the corresponding one-week periods are also presented.

Table 2 shows that the average nanoparticle concentrations measured outdoors during the heating season were in most cases higher in comparison with the average nanoparticle concentrations measured during the non-heating season. The mixing layer can greatly affect the differences in nanoparticle concentrations during the different seasons and 
during the different weeks. Meteorological data during the measurement periods are presented in Appendix A, Table A1. As Umeå is situated in northern Sweden, periods of low temperature ( $\mathrm{min}-21.9^{\circ} \mathrm{C}$ during the measurement period) and low wind speed ( $\mathrm{min}$ $1.7 \mathrm{~m} / \mathrm{s}$ during the measurement period) occurred.

During these two one-week measurement periods, there were large daily variations in nanoparticle concentrations. For example, Figure 4 presents the 5 -min average nanoparticle number concentrations measured in Building 11, where relatively high indoor concentrations were found during one week in the heating season and during one week in the non-heating season. Building 11 is located close to a bus terminal where the impact of nanoparticles from the outdoor air is high. During these two one-week periods, the concentrations fluctuated sharply both outdoors and indoors. In general, the concentrations were higher on weekdays during the daytime; however, in several cases, high concentrations also appeared in the late evenings. Thus, it is difficult to determine any clear temporal trend.

Table 3. Maximum and minimum concentrations measured indoors and outdoors during the heating and the non-heating seasons.

\begin{tabular}{|c|c|c|c|c|c|}
\hline \multirow{2}{*}{$\begin{array}{l}\text { Buildings } \\
\quad 1-12\end{array}$} & \multicolumn{2}{|c|}{$\begin{array}{l}\text { Indoor Concentration } \\
\left(\text { Particles per } \mathrm{cm}^{3}\right)\end{array}$} & \multicolumn{2}{|c|}{$\begin{array}{l}\text { Outdoor Concentration } \\
\left(\text { Particles per } \mathrm{cm}^{3}\right)\end{array}$} & \multirow{2}{*}{$\begin{array}{l}\text { Distance } \\
\text { from Busy } \\
\text { Street (m) }\end{array}$} \\
\hline & Maximum & Minimum & Maximum & Minimum & \\
\hline \multicolumn{6}{|c|}{ Heating Season } \\
\hline 1 & 32,357 & 462 & 283,275 & 560 & 850 \\
\hline 2 & 3274 & 0 & 36,129 & 256 & 790 \\
\hline 3 & 4454 & 45 & 176,261 & 72 & 700 \\
\hline 4 & 1806 & 19 & 21,809 & 33 & 500 \\
\hline 5 & 1093 & 0 & 432,664 & 57 & 860 \\
\hline 6 & 2542 & 0 & 164,311 & 500 & 920 \\
\hline 7 & 1596 & 0 & 71,732 & 361 & 970 \\
\hline 8 & 1765 & 46 & 155,486 & 121 & 570 \\
\hline 9 & 2621 & 12 & 208,114 & 147 & 680 \\
\hline 10 & 5652 & 67 & 53,763 & 54 & 250 \\
\hline 11 & 27,461 & 368 & 164,311 & 166 & 130 \\
\hline 12 & 3878 & 55 & 202,679 & 317 & 550 \\
\hline \multicolumn{6}{|c|}{ Non-Heating Season } \\
\hline 1 & 5291 & 0 & 149,128 & 179 & 850 \\
\hline 2 & 1325 & 45 & 353,910 & 768 & 790 \\
\hline 3 & 4578 & 156 & 118,288 & 240 & 700 \\
\hline 4 & 44,613 & 0 & 198,795 & 710 & 500 \\
\hline 5 & 2461 & 114 & 149,128 & 179 & 860 \\
\hline 6 & 5528 & 228 & 88,736 & 278 & 920 \\
\hline 7 & 1456 & 88 & 64,052 & 303 & 970 \\
\hline 8 & 1945 & 118 & 522,546 & 4332 & 570 \\
\hline 9 & 3547 & 392 & 30,931 & 638 & 680 \\
\hline 10 & 2802 & 63 & 32,344 & 717 & 250 \\
\hline 11 & 4784 & 94 & 241,334 & 683 & 130 \\
\hline 12 & 4093 & 249 & 201,487 & 831 & 550 \\
\hline
\end{tabular}



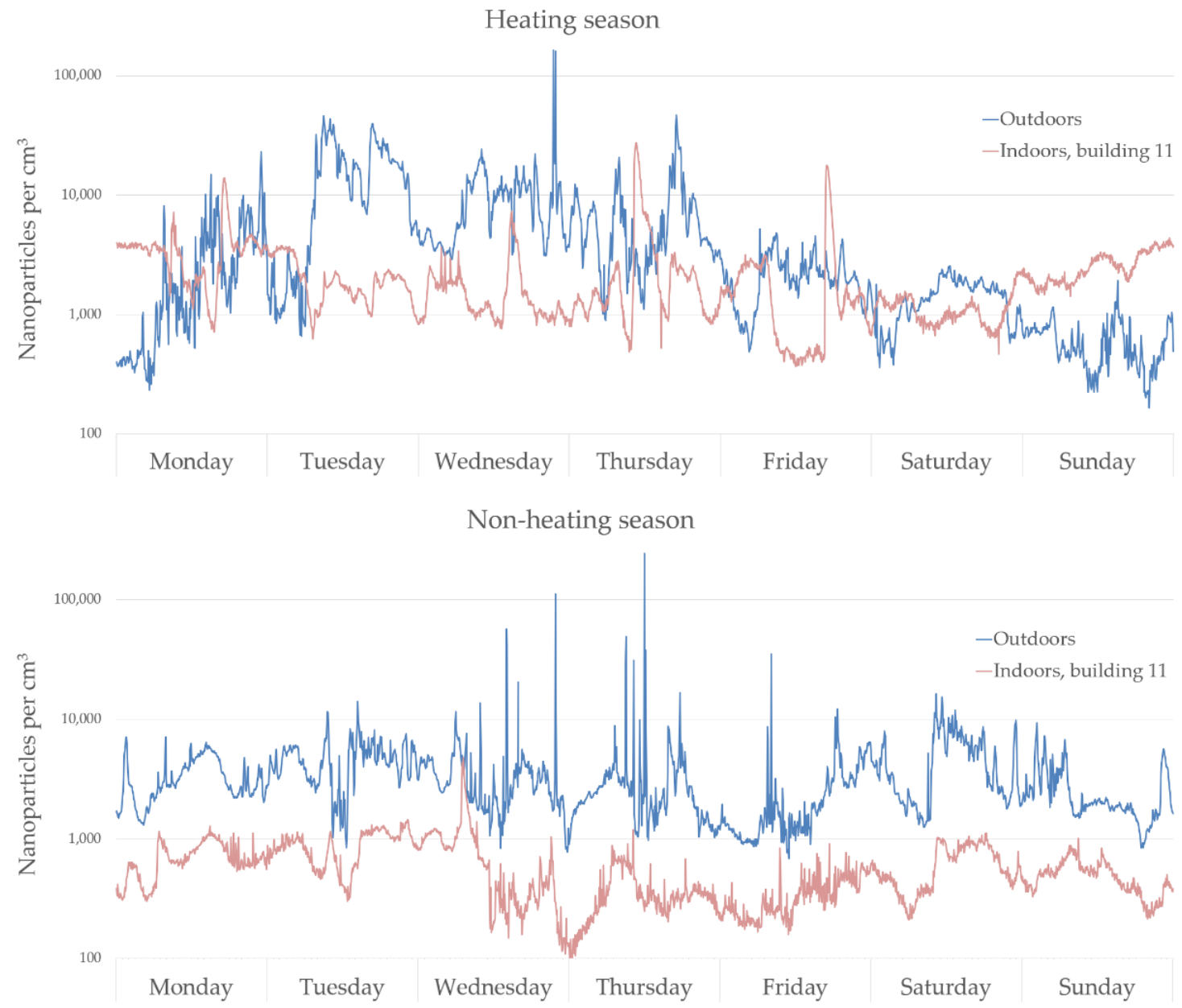

Figure 4. The weekly variations in nanoparticle concentrations indoors in Building 11 and outdoors during heating and non-heating seasons presented on a logarithmic scale.

In Figure 5, the number concentration of particles in different size classes are presented for three office buildings during the heating and the non-heating seasons (see Buildings 7 , 8 , and 11 in Tables 2 and 3). Building 7 represents an older office building, $970 \mathrm{~m}$ from a busy street. In Building 7, the highest nanoparticle concentrations during both the heating and the non-heating seasons are shown at a size of about $50 \mathrm{~nm}$. Building 8 represents an older office building, $570 \mathrm{~m}$ from a busy street. In Building 8, the highest nanoparticle concentrations during both the heating and the non-heating seasons are shown at the size of about $65 \mathrm{~nm}$. Building 11 represents an older office building, $130 \mathrm{~m}$ from a busy street and $170 \mathrm{~m}$ from a bus terminal. The particle concentrations during the heating season were very high, especially for particles in the size range of 12-15 nm. However, during the non-heating season, the particle concentrations in the different size fractions in Building 11 were quite similar to those in the other buildings. 

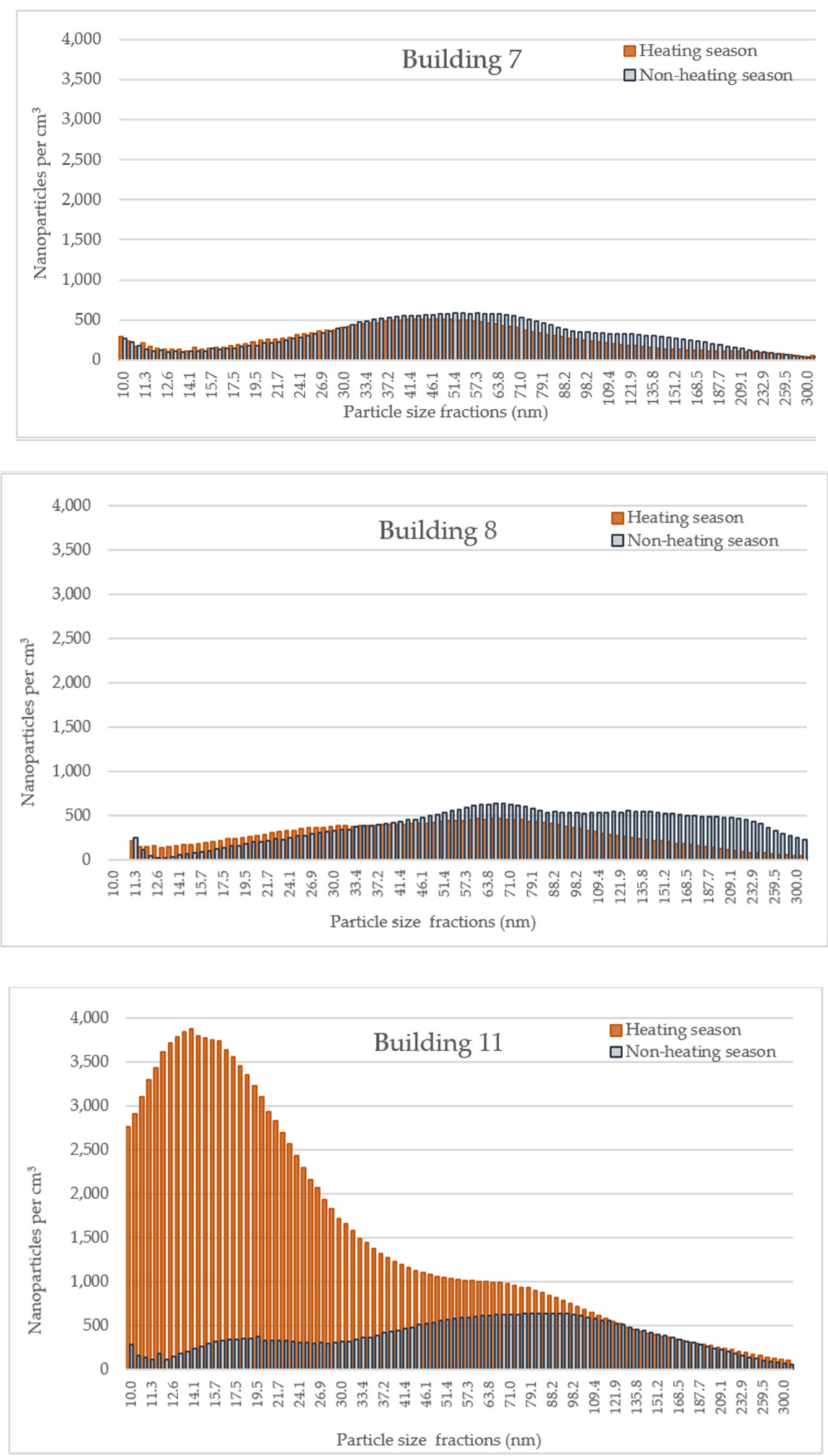

Figure 5. Concentrations of nanoparticles in different size fractions (10-300 nm) during the heating and the non-heating seasons in three buildings located at different distances from a busy street. Top: Building 7 (older office building, $970 \mathrm{~m}$ from a busy street). Middle: Building 8 (older office building, $570 \mathrm{~m}$ from a busy street). Bottom: Building 11 (older office building, $130 \mathrm{~m}$ from a busy street and $170 \mathrm{~m}$ from a bus terminal). 


\section{Discussion}

\subsection{Outdoor Nanoparticles and Their Infiltration Indoors}

Indoor nanoparticle concentrations are driven by both indoor and outdoor sources. The indoor sources, such as indoor combustion, office equipment, etc., emit particles directly into the indoor air, whereas outdoor particles are deposited indoors mainly through infiltration or ventilation. In the current study, the average indoor concentrations were lower in comparison with the outdoor concentrations in all cases. During the outdoor peak concentrations, the indoor concentrations were usually also higher, indicating that outdoor infiltration affects the indoor concentrations of nanoparticles. In one of the studied buildings close to a bus terminal (Building 11), the indoor concentrations measured on weekdays during daytime turned out to be higher in comparison with the indoor concentrations measured during nighttime and on weekends, again indicating emissions of CFNP. The Pearson correlation coefficients between indoor and outdoor concentrations (Table 2) show large variations, but seven R-values in the range of $0.41-0.89$ indicate that infiltration occurs. The large variations in the correlation coefficients can be caused by meteorological factors in terms of wind speed and the mixing layer. However, there were also several periods with relatively high indoor concentrations in connection with relatively low outdoor concentrations, which indicates that the indoor sources are also of crucial importance for the nanoparticles measured indoors.

The importance of outdoor air in terms of indoor air quality has been shown in several earlier studies focusing on the I/O relationships of particles in school buildings in different areas. In a study from Brazil, particles in the size range of $10-420 \mathrm{~nm}$ were analyzed at rural and urban preschools in 2016-2017. The average I/O ratios of nanoparticle concentrations during the study period were 0.91 and 0.51 at the rural and the urban preschools, respectively. The I/O concentration ratios were also higher during morning and afternoon rush hours, indicating the importance of the contribution of vehicle exhaust from the outdoor air as a source of nanoparticles indoors [39]. In our study, the lower I/O ratios could be explained by longer distances from busy streets and/or relatively high outdoor concentrations. The impact of traffic on indoor air quality has also been shown in four preschools in Bogota, Colombia, where the concentrations of $\mathrm{PM}_{10}, \mathrm{PM}_{2.5}$, and black carbon were higher in those schools located alongside major urban roads [53]. Based on measurements of UFPs in 39 naturally ventilated primary schools in Barcelona, Spain, traffic emissions were estimated to be an important source of nanoparticles both indoors and outdoors [37]. In Umeå, residential wood combustion also has an important role in affecting ambient air quality [54]; however, houses near the measuring sites have district heating connected to a boiler house situated outside the city.

The indoor-outdoor relationships of particles have also been examined in residential houses. In a study from Australia, the indoor-outdoor relationships for particles in different size classes were measured in 16 residential houses located in a suburban area of Brisbane. The I/O ratios of sub-micrometer particles were in the range of 0.78 to 1.07, leading to the overall conclusion that during normal ventilation conditions, the particle concentrations measured outdoors could be used to predict simultaneous particle concentrations indoors [55]. In homes in Oporto, Portugal, UFP concentrations were higher indoors than outdoors and were spatially varied, being highest in kitchens, lower in living rooms and lowest in bedrooms [56]. In a study from Somerville, Massachusetts, U.S., the PNC in the size range of 6-3000 nm was measured both indoors and outdoors at 18 homes located $<1500 \mathrm{~m}$ from an Interstate Highway. It appeared that the indoor and outdoor PNCs of homes located $<100 \mathrm{~m}$ from the highway were higher in comparison with homes located $>1000 \mathrm{~m}$ away [40]. In addition, in the current study, nanoparticle concentrations in offices located $<250 \mathrm{~m}$ from a busy street seemed to be higher compared to offices $>500 \mathrm{~m}$ away. Furthermore, in the study by Fuller et al. [40], the I/O concentration ratios were generally high, with a median value of 0.95 pooled over all homes. In a regression model based on these indoor and outdoor PNCs, an increase in outdoor PNC was associated with an approximately equal increase indoors. A high correlation between $\mathrm{I} / \mathrm{O}$ concentrations 
and high infiltration, especially during summer, has also been shown in Chinese cities [57]. In the current study, I/O ratios were significantly lower than in China.

Considering the results of this current study, no general conclusions regarding the I/O concentration ratios and indoor infiltration can be made, as there were high temporal variations and large differences between the buildings.

To sum up, the nanoparticle concentrations indoors are influenced by the concentrations outdoors; nevertheless, the association seems to be complex and difficult to trace. In this study, the nanoparticle concentrations measured indoors were generally high in connection with outdoor peak concentrations. However, there were also some periods with relatively high indoor concentrations in connection with relatively low outdoor concentrations (Figure 4), which indicates that indoor sources are also a contributing factor, especially in Building 1.

\subsection{Indoor Sources}

Although CFNPs originating from traffic are an important source of nanoparticles that infiltrate indoors, as we can see in the current study, there are also a number of indoor sources that generate nanoparticles, such as cooking, smoking, candle burning, and electrical appliances [52]. Reche et al. [37] have described specific cases in which the indoor concentrations exceeded the outdoor concentrations, which could possibly be caused by cooking activities and surface chemistry reactions mediated by ozone.

Building activities have also been shown to be a significant source of nanoparticles. In the current study, the highest concentrations of indoor nanoparticles were found in recently opened office buildings. Measurements of ultrafine particles during building activities such as crushing, demolition and recycling concrete indicated that the majority of the number of newly formed particles were in the size range of $<100 \mathrm{~nm}$ [58]. Newly built or renovated buildings can also emit volatile organic compounds (VOCs) [59]. Subsequently, VOCs can react with the indoor ozone and produce nanoparticles [60]. The particle levels are high indoors, which indicates that indoor sources are also important.

Nanoparticles originating from biological materials are also well represented in the indoor environment [61]. There are many indoor sources of these so-called bioaerosols, including mold on building materials, occupants, pets, indoor plants, and organic waste. As the measuring devices currently used do not enable study of the chemical composition of nanoparticles, we cannot draw conclusions about the role of bioaerosols.

Earlier studies have indicated that office equipment can also generate nanoparticles. Laser printers are commonly used in offices, and many studies have shown that they can release particles and produce adverse effects on indoor air quality. A test with printers in a clean chamber indicated that the emitted particles were dominated by particles in nanoscale [62]. It has also been shown in a chamber study that the nanoparticles emitted from laser printers have a bimodal number size distribution: one smaller mode with particles $<10 \mathrm{~nm}$ and one larger mode in the size range of $40-100 \mathrm{~nm}$. Nanoparticles in these two size distributions were detected even when the laser printers were activated without toner or paper. This indicates that the fuser unit, which is the device that that fixes toner on the paper with heat, is the primary source of nanoparticles emitted from laser printers [63]. From a health perspective, the particles emitted from laser printers are considered to pose relatively lower health risks in comparison with other particles, i.e., CDNPs, commonly found in the ambient air [21]. All offices in the current study had laser printers; however, none of them were in the same room where the measurements took place.

\subsection{Processes That Determine the Particle Properties Indoors and Outdoors}

An overall pattern of the measurement results in this study was higher number concentrations of particles measured outdoors, while the particle sizes measured indoors were larger in comparison with the particles measured outdoors. Outdoor air infiltration is assumed to be an important source of the nanoparticles measured indoors [55]. The 
buildings with old ventilation systems located close to heavy traffic are especially affected by nanoparticles originating outdoors [64].

Particles originating from combustion processes mainly occur in two size classes: nanoparticles in the size range of 1-5 $\mathrm{nm}$ and soot particles in the size range of 10-100 $\mathrm{nm}$ [10]. These two size ranges represent two different modes, referred to as nucleation mode and Aitken mode. In terms of particle number concentration per volume unit, most of the measured particles in the current study are represented in the Aitken mode (from around 10 to $100 \mathrm{~nm}$ ), while in terms of particle mass per volume unit, the particles $>100 \mathrm{~nm}$ dominate (called accumulation mode), since they are significantly larger but significantly fewer in number. The nucleation process is a gas-to-particle conversion in which nanoparticles are formed from gaseous molecules (homogeneous nucleation) and then grow larger by condensation of other gaseous molecules (heterogeneous nucleation) and by coagulation with other nucleated particles [63].

The overall pattern of higher number concentrations of particles measured outdoors but larger particle sizes measured indoors can largely be explained by the condensation and the coagulation processes: i.e., the particles are emitted mainly from the traffic outdoors, and as they penetrate into the buildings, condensation and coagulation of nucleated particles increase the average size while the number concentration decreases. This could also explain the relatively low correlation coefficients between the number concentrations indoors and outdoors. When comparing the concentrations of nanoparticles in different size fractions (Figure 5), it appears, especially during the heating season, that the concentration of particles in the size range of 10-20 nm (Aitken mode) was particularly high in the office building close to a bus terminal. It is also shown in Figure 5 that there were relatively larger proportions of particles in the larger size classes in the buildings further away from the bus terminal.

In the current study, we could see differences in particle concentrations during the heating and the non-heating seasons, with higher average concentrations both indoors and outdoors during the heating season. This could be explained by several different factors. Firstly, more intense traffic in combination with a more stable atmosphere with lower wind speeds can partly explain the higher average nanoparticle concentration in the heating season during wintertime [65]. Secondly, nanoparticle formation processes are also influenced by the temperature. Increased particle formation from nucleation of exhaust from combustion engines has been shown to occur during cold days [39]. An increase in particle number concentration associated with decreasing temperatures has also been shown based on measurements in a street canyon in Stockholm during the period of 2002-2004. The increase in particle concentration associated with decreasing temperature was most noticeable for particles smaller than $40 \mathrm{~nm}$ [66]. The higher concentration of larger fine particles in winter compared to summer was previously identified in the OFFICAIR study [67].

The results presented in Figure 5, which shows the size fractions of nanoparticles measured indoors, give some indications that the factors mentioned above at least partially control the nanoparticle concentrations. During the heating season, the smaller size fractions (10-30 nm) of the indoor measurements in Building 11 (Figure 5) show a relatively large number of particles in comparison with the indoor measurements in Building 7 and Building 8. Building 11 is located $130 \mathrm{~m}$ from a busy street and $170 \mathrm{~m}$ from a bus terminal. As shown in Table A1, the average temperature was relatively low during the measurement period for Building 11, but the wind speed during this week $(1.7 \mathrm{~m} / \mathrm{s})$ was the lowest of all 24 weeks in which the measurements were performed. This might partly explain the relatively high concentrations of small particles $(10-30 \mathrm{~nm})$ measured indoors. The effect of low wind speeds and very low mixing layer heights on UFP dispersion has been discussed by Giemsa et al. [68].

In addition to the mechanisms described above, which mainly contribute to the nanoparticle concentrations during the heating season, there are also mechanisms that are most prominent during the non-heating season that benefit the formation of nanoparticles. 
Photochemically induced nucleation with the influence of sunlight is another formation mechanism that can contribute as much as local traffic to particle number concentration [69] and is most prominent during the summer [58]. However, Umeå is located at 63 degrees north latitude, and photochemically induced nucleation is probably significantly less prominent there in comparison with cities located closer to the equator.

Moreover, there are certain processes in addition to emissions that have a major impact on the PNC measured at different locations at different times within a city. Particle dynamics are particularly important to consider as they largely affect particles smaller than $20 \mathrm{~nm}$ [70]. Model calculations of PNC in Stockholm by Gidhagen et al. [71] show episodic losses of nanoparticles due to coagulation and dry deposition. Similar results based on calculations of PNC have been found in Oslo, Helsinki and Rotterdam by Karl et al. [72].

\subsection{Strengths and Limitations of This Study}

A main strength of this study is that it utilizes extensive datasets with continuous measurements of nanoparticles both indoors and outdoors at twelve different buildings that were chosen to represent different distances from busy streets. The measurements are also divided into two periods representing both the heating and the non-heating seasons, which is an advantage for understanding differences in the processes that create nanoparticles at different temperatures. Also, measurements lasted for a whole week-including working days and a weekend-and thus show fluctuations during different times and days of the week.

A limitation of this study is that the outdoor measurements were all performed at the same measurement point. In order to establish accurate relationships between indoor and outdoor concentrations, it would have been more beneficial to measure the outdoor concentrations in close proximity to each building. Unfortunately, this was not possible due to technical needs and restrictions from building owners. Thus, local outdoor sources of nanoparticles in close proximity to a building could not be detected from the outdoor measurement point. The highly variable and generally small correlation coefficients between the indoor and the outdoor concentrations (Table 2) can probably be at least partly explained by the lack of outdoor measurements in close proximity to the buildings where the indoor measurements were performed. Also, we used two different devices for measurements. Despite relatively good agreement between SMPS and DISCmini in some studies $[49,50]$, several studies have also identified difference in number concentration when different devices were used $[73,74]$.

Another limitation of this study is that only the number concentration of nanoparticles was measured. With this applied methodology, it is not possible to distinguish the sources and chemical composition of the measured nanoparticles. This is an important issue that needs to be addressed in future studies. By knowing the chemical composition, it is easier to trace the various sources of nanoparticles, especially indoors [75-77].

We included in this study particles in the size range of 10-300 nm in order to have a similar size fraction covered by two different devices. Nanoparticles are often defined as particles $<100 \mathrm{~nm}$ in diameter in at least one dimension. However, from a health perspective, particles in the size range up to $300 \mathrm{~nm}$ are important since they are capable of diffusing rapidly in human airway mucus through the mucus pores [5,6]. Nevertheless, the majority of the particles that were measured in this study were in the size range of $10-100 \mathrm{~nm}$.

Another limitation of this study is that the particles in the size range of $<10 \mathrm{~nm}$ (sub-10 nm) were not measured. However, these particles are not easy to measure, and the health effects associated with exposure to those particles are not very well known [78]. Modern technologies and wider use of biofuels reduces the total mass concentration of particles in the exhaust, but might increase the number concentration of sub-10 nm particles [79]. Particles in the size range of 1.3-10 nm can also be generated from brake wear [80]. Indoor laser printers are another source of sub- $10 \mathrm{~nm}$ particles, where the emitted particles have a bimodal number size distribution with one smaller mode with 
particles $<10 \mathrm{~nm}$ [57]. To sum up, particles smaller than $10 \mathrm{~nm}$ can arise from several sources, and these particles are also important to consider regarding their potential health effects in further studies.

\subsection{Regulatory Outlook}

In the current study, relatively high concentrations of nanoparticles were found (up to half a million particles per $\mathrm{cm}^{3}$ in outdoor air); however, there are no limit values for nanoparticles/UFPs in ambient air. The World Health Organization is now reviewing and updating its air quality guidelines with a special focus on UFPs in future documents. Nevertheless, in epidemiological studies, the evidence of health effects associated with exposure to UFPs has been inconclusive, especially for short-term effects [32]. Further evidence of long-term health effects associated with exposure to UFPs has recently been published [33].

In occupational environments, a few recommended time-weighted average exposure limits for specific UFPs—-such as titanium dioxide, silver, and nanofibers-exist, but overall, there are currently no regulations for UFPs in general in occupational environments such as offices [81-83]. Further implementation of workplace exposure limits for nanoparticles in the range of $0-100 \mathrm{~nm}$ have been proposed [84]. Occupational exposure limits for nanomaterials and nanoparticles have been discussed in van Broekhuizen et al. [85], and a set of 'Nano reference values' has been proposed in the Netherlands [86]. In office environments, the emissions from laser printers has been limited with the BLUE Angel Certification, which has set an emission limit value of $3.5 \times 10^{11}$ particles during $10 \mathrm{~min}$ of printing in monochrome mode [87]. Despite this, as discussed earlier, high levels of nanoparticles are released by printers, which could produce adverse effects on indoor air quality [62].

\section{Conclusions}

The current study identified the highest nanoparticle concentrations in offices close to a bus terminal and the lowest in offices near a park, indicating the influence of trafficinduced, combustion-formed nanoparticles (CFNPs). Also, a temporal effect appeared, usually with higher concentrations of nanoparticles found during daytime in the urban background area, whereas considerably lower nanoparticle concentrations were often present during nighttime. Infiltration of nanoparticles from the outdoor air into the indoor air was also common, as the nanoparticle concentrations measured indoors were generally high in connection with outdoor peak concentrations. However, overall conclusions are difficult to draw, since the I/O ratios showed large variations between buildings, seasons, and time periods. In general, the higher average nanoparticle concentrations during the heating season (both indoors and outdoors) could be explained by more intense traffic in combination with a more stable atmosphere with lower wind speeds, but also by increased particle formation from nucleation of exhaust during cold days.

Even though the indoor sources of nanoparticles have also been shown to be important, in the current study, high/low indoor particle concentrations usually appeared in connection with high/low outdoor concentrations. However, the highest concentrations of indoor nanoparticles were found in recently opened office buildings, which could be affected by new building conditions. As only the number concentrations of nanoparticles were measured in the current study, it was not possible to distinguish the sources and chemical composition of the measured nanoparticles. This is an important issue that needs to be addressed in future studies.

Author Contributions: Conceptualization: H.O. (Hans Orru) and A.H.; Methodology: H.O. (Hans Orru) and A.H.; Data analysis: H.O. (Hans Orru), A.H. and H.O. (Henrik Olstrup); Writing-original draft preparation: H.O. (Henrik Olstrup) and H.O. (Hans Orru); Writing-review and editing A.H. All authors have read and agreed to the published version of the manuscript.

Funding: This research was funded by FORMAS, grant number 2015-01557. 
Institutional Review Board Statement: Not applicable.

Informed Consent Statement: Not applicable.

Data Availability Statement: The data presented in this study are available on request from the corresponding author.

Acknowledgments: We would like to thank Norrland University Hospital, the National Board of Housing, Building and Planning, Akademiska Hus AB and the Swedish Energy Agency for their cooperation and for providing technical details about the buildings, especially Lars Holmström, Tomas Andersson, Lars Karlsson, Maria Hammeryd, and Simon Burman. We would also like to acknowledge Kristina Lindblom and Tanel Tamm for their technical support.

Conflicts of Interest: The authors declare no conflict of interest.

\section{Appendix A}

Table A1. Meteorological characteristics at Umea meteorological station during the measurement periods in the heating and the non-heating seasons.

\begin{tabular}{|c|c|c|c|c|c|c|c|c|}
\hline $\begin{array}{l}\text { Buildings } \\
1-12\end{array}$ & $\begin{array}{c}\text { Measurement } \\
\text { Period, } \\
\text { Heating } \\
\text { Season }\end{array}$ & $\begin{array}{c}\text { Temp, } \\
\text { Average } \\
\text { (Min, Max) } \\
\left({ }^{\circ} \mathrm{C}\right)\end{array}$ & $\begin{array}{l}\text { Wind Speed } \\
(\mathrm{m} / \mathrm{s})\end{array}$ & $\begin{array}{c}\text { Relative } \\
\text { Humidity } \\
\text { (\%) }\end{array}$ & $\begin{array}{l}\text { Measurement } \\
\text { Period, Non- } \\
\text { Heating } \\
\text { Season }\end{array}$ & $\begin{array}{c}\text { Temp, } \\
\text { Average } \\
(\text { Min, Max) } \\
\left({ }^{\circ} \mathrm{C}\right)\end{array}$ & $\begin{array}{l}\text { Wind Speed } \\
(\mathrm{m} / \mathrm{s})\end{array}$ & $\begin{array}{c}\text { Relative } \\
\text { Humidity } \\
(\%)\end{array}$ \\
\hline 1 & $\begin{array}{c}29 \text { March } \\
\text { 2018-5 April } \\
2018\end{array}$ & $\begin{array}{c}-3.3 \\
(-15.9,6.1)\end{array}$ & 2.1 & 77.5 & $\begin{array}{c}\text { 31 May } \\
\text { 2018-7 June } \\
2018\end{array}$ & $\begin{array}{c}13.0 \\
(0,25.7)\end{array}$ & 4.6 & 52.7 \\
\hline 2 & $\begin{array}{l}\text { 4-11 April } \\
2017\end{array}$ & $\begin{array}{c}2.5 \\
(-2.8,10.3)\end{array}$ & 2.7 & 78.2 & $\begin{array}{l}29 \text { June } \\
\text { 2017-6 July } \\
2017\end{array}$ & $\begin{array}{c}14.0 \\
(2.4,22.0)\end{array}$ & 3.5 & 68.6 \\
\hline 3 & $\begin{array}{c}\text { 13-20 March } \\
2017\end{array}$ & $\begin{array}{c}0.3 \\
(-11.7,7.6)\end{array}$ & 3.4 & 83.0 & $\begin{array}{c}\text { 24-31 May } \\
2017\end{array}$ & $\begin{array}{c}9.0 \\
(-2.3,18.5)\end{array}$ & 3.6 & 65.2 \\
\hline 4 & $\begin{array}{c}\text { 21-28 March } \\
2017\end{array}$ & $\begin{array}{c}2.2 \\
(-6.2,11.1)\end{array}$ & 5.1 & 69.1 & $\begin{array}{l}\text { 6-14 July } \\
2017\end{array}$ & $\begin{array}{c}14.0 \\
(2.4,21.1)\end{array}$ & 2.6 & 77.1 \\
\hline 5 & $\begin{array}{c}\text { 5-12 January } \\
2018\end{array}$ & $\begin{array}{c}-6.5 \\
(-18.5,3.4)\end{array}$ & 3.1 & 88.7 & $\begin{array}{l}\text { 7-14 June } \\
2018\end{array}$ & $\begin{array}{c}10.7 \\
(0,22.4)\end{array}$ & 2.9 & 69.5 \\
\hline 6 & $\begin{array}{c}16-23 \\
\text { January } 2018\end{array}$ & $\begin{array}{c}-8.0 \\
(-21.9,0.6)\end{array}$ & 3.2 & 90.3 & $\begin{array}{c}\text { 26 June } \\
\text { 2018-3 July } \\
2018\end{array}$ & $\begin{array}{c}14.7 \\
(2.1,23.4)\end{array}$ & 3.4 & 57.6 \\
\hline 7 & $\begin{array}{c}\text { 21-28 March } \\
2018\end{array}$ & $\begin{array}{c}-4.0 \\
(-19.8,4.7)\end{array}$ & 2.9 & 75.5 & $\begin{array}{l}\text { 18-25 June } \\
2018\end{array}$ & $\begin{array}{c}13.5 \\
(3.6,22.5)\end{array}$ & 4.0 & 68.0 \\
\hline 8 & $\begin{array}{c}15-22 \\
\text { February } \\
2017\end{array}$ & $\begin{array}{c}-2.9 \\
(-20.2,6.4)\end{array}$ & 2.3 & 89.2 & $\begin{array}{l}\text { 16-23 June } \\
2017\end{array}$ & $\begin{array}{c}13.4 \\
(3.6,22.7)\end{array}$ & 3.3 & 71.1 \\
\hline 9 & $\begin{array}{c}28 \text { March } \\
\text { 2017-4 April } \\
2017\end{array}$ & $\begin{array}{c}-0.2 \\
(-8.8,9.6)\end{array}$ & 3.4 & 78.4 & $\begin{array}{l}\text { 7-14 June } \\
2017\end{array}$ & $\begin{array}{c}13.3 \\
(4.1,22.4)\end{array}$ & 2.9 & 76.9 \\
\hline 10 & $\begin{array}{c}23-30 \\
\text { January } 2017\end{array}$ & $\begin{array}{c}-0.5 \\
(-11.1,8.0)\end{array}$ & 3.2 & 87.3 & $\begin{array}{c}25 \text { July } \\
2017-1 \\
\text { August 2017 }\end{array}$ & $\begin{array}{c}16.8 \\
(5.6,22.2)\end{array}$ & 2.7 & 81.9 \\
\hline 11 & $\begin{array}{c}\text { 2-9 February } \\
2017\end{array}$ & $\begin{array}{c}-6.0 \\
(-19.5,0.1)\end{array}$ & 1.7 & 90.4 & $\begin{array}{l}\text { 31 May } \\
\text { 2017-7 June } \\
2017\end{array}$ & $\begin{array}{c}8.5 \\
(-2.1,21.4)\end{array}$ & 3.7 & 68.5 \\
\hline 12 & $\begin{array}{c}\text { 3-10 March } \\
2017\end{array}$ & $\begin{array}{c}-6.4 \\
(-19.3,6.2)\end{array}$ & 2.3 & 89.0 & $\begin{array}{c}\text { 17-24 July } \\
2017\end{array}$ & $\begin{array}{c}14.1 \\
(5.4,22.5)\end{array}$ & 2.9 & 76.0 \\
\hline
\end{tabular}

\section{References}

1. Barua, S.; Mitragotri, S. Challenges associated with penetration of nanoparticles across cell and tissue barriers: A review of current status and future prospects. Nano Today 2014, 9, 223-243. [CrossRef]

2. Laurent, S.; Forge, D.; Port, M.; Roch, A.; Robic, C.; Vander Elst, L.; Muller, R.N. Magnetic Iron Oxide Nanoparticles: Synthesis, Stabilization, Vectorization, Physicochemical Characterizations, and Biological Applications. Chem. Rev. 2008, 108, 2064-2110. [CrossRef]

3. Höck, J.; Epprecht, T.; Hofmann, H.; Höhner, K.; Krug, H.; Lorenz, C.; Limbach, L.; Gehr, P.; Nowack, B.; Riediker, M. Guidelines on The Precautionary Matrix for Synthetic Nanomaterials; Federal Office for Public Health and Federal Office for the Environment: Bern, Switzerland, 2010.

4. Commission, E. Commission recommendation of 18 October 2011 on the definition of nanomaterial. Off. J. Eur. Union 2011, 275,38 . 
5. Schuster, B.S.; Suk, J.S.; Woodworth, G.F.; Hanes, J. Nanoparticle diffusion in respiratory mucus from humans without lung disease. Biomaterials 2013, 34, 3439-3446. [CrossRef]

6. Schneider, C.S.; Xu, Q.; Boylan, N.J.; Chisholm, J.; Tang, B.C.; Schuster, B.S.; Henning, A.; Ensign, L.M.; Lee, E.; Adstamongkonkul, P.; et al. Nanoparticles that do not adhere to mucus provide uniform and long-lasting drug delivery to airways following inhalation. Sci. Adv. 2017, 3, e1601556. [CrossRef]

7. Yang, Y.; Qin, Z.; Zeng, W.; Yang, T.; Cao, Y.; Mei, C.; Kuang, Y. Toxicity assessment of nanoparticles in various systems and organs. Nanotechnol. Rev. 2017, 6, 279-289. [CrossRef]

8. Rodríguez, F.; Bernard, Y.; Dornoff, J.; Mock, P. Recommendations for post-Euro 6 standards for light-duty vehicles in the European Union. Communications 2019, 49. Available online: https://theicct.org/publications/recommendations-post-euro-6-eu (accessed on 1 July 2021).

9. Myung, C.L.; Park, S. Exhaust nanoparticle emissions from internal combustion engines: A review. Int. J. Automot. Technol. 2012, 13, 9-22. [CrossRef]

10. D'Anna, A. Combustion-formed nanoparticles. Proc. Combust. Inst. 2009, 32, 593-613. [CrossRef]

11. Karner, A.A.; Eisinger, D.S.; Niemeier, D.A. Near-roadway air quality: Synthesizing the findings from real-world data. Environ. Sci. Technol. 2010, 44, 5334-5344. [CrossRef] [PubMed]

12. Viitanen, A.-K.; Uuksulainen, S.; Koivisto, A.J.; Hämeri, K.; Kauppinen, T. Workplace Measurements of ultrafine particles-A literature review. Ann. Work. Expo. Health 2017, 61, 749-758. [CrossRef]

13. Grigoratos, T.; Martini, G. Non-exhaust traffic related emissions. Brake and tyre wear PM. Rep. No. Rep. EUR 2014, 26648, 7-9.

14. Maher, B.A.; Ahmed, I.A.M.; Karloukovski, V.; MacLaren, D.A.; Foulds, P.G.; Allsop, D.; Mann, D.M.A.; Torres-Jardón, R.; Calderon-Garciduenas, L. Magnetite pollution nanoparticles in the human brain. Proc. Natl. Acad. Sci. USA 2016, 113, 10797-10801. [CrossRef]

15. Kazimirova, A.; Peikertova, P.; Barancokova, M.; Staruchova, M.; Tulinská, J.; Vaculik, M.; Vávra, I.; Kukutschova, J.; Filip, P.; Dusinska, M. Automotive airborne brake wear debris nanoparticles and cytokinesis-block micronucleus assay in peripheral blood lymphocytes: A pilot study. Environ. Res. 2016, 148, 443-449. [CrossRef]

16. Walser, T.; Limbach, L.K.; Brogioli, R.; Erismann, E.; Flamigni, L.; Hattendorf, B.; Juchli, M.; Krumeich, F.; Ludwig, C.; Prikopsky, K.; et al. Persistence of engineered nanoparticles in a municipal solid-waste incineration plant. Nat. Nanotechnol. 2012, 7, 520-524. [CrossRef] [PubMed]

17. Costa, M.A.M.; Fogarin, H.M.; Costa, A.F.M.; Pires, L.O.; Silva, D.D.V.; Lima-Souza, M.; Dussán, K.J. Nanoparticles emitted by biomass burning: Characterization and monitoring of risks. In Nanomaterials: Ecotoxicity, Safety, and Public Perception; Springer Science and Business Media LLC.: Cham, Switzerland, 2018; pp. 253-279.

18. Shukhnova, A.; Bozrova, S.; Sokolov, P.; Berestovoy, M.; Karaulov, A.; Nabiev, I. Dependence of nanoparticle toxicity on their physical and chemical properties. Nanoscale Res. Lett. 2018, 13, 1-21. [CrossRef]

19. Wallace, L.A.; Ott, W.R.; Weschler, C.J. Ultrafine particles from electric appliances and cooking pans: Experiments suggesting desorption/nucleation of sorbed organics as the primary source. Indoor Air 2014, 25, 536-546. [CrossRef] [PubMed]

20. Kaluza, S.; Balderhaar, J.K.; Orthen, B.; Honnert, B.; Jankowska, E.; Pietrowski, P.; Rosell, M.; Tanarro, C.; Tejedor, J.; Zugasti, A. Literature Review - Workplace Exposure to Nanoparticles; EU-OSHA-European Agency for Safety and Health at Work: Bilbao, Spain, 2009.

21. Gu, J.; Karrasch, S.; Salthammer, T. Review of the characteristics and possible health effects of particles emitted from laser printing devices. Indoor Air 2020, 30, 396-421. [CrossRef] [PubMed]

22. Spiru, P.; Simona, P.L. A review on interactions between energy performance of the buildings, outdoor air pollution and the indoor air quality. Energy Procedia 2017, 128, 179-186. [CrossRef]

23. Bone, A.; Murray, V.; Myers, I.; Dengel, A.; Crump, D. Will drivers for home energy efficiency harm occupant health? Perspect. Public Health 2010, 130, 233-238. [CrossRef] [PubMed]

24. Moreno-Rangel, A.; Sharpe, T.; McGill, G.; Musau, F. Indoor air quality in passivhaus dwellings: A literature review. Int. J. Environ. Res. Public Health 2020, 17, 4749. [CrossRef]

25. Lespes, G.; Faucher, S.; Slaveykova, V.I. Natural nanoparticles, anthropogenic nanoparticles, where is the frontier? Front. Environ. Sci. 2020, 8, 71. [CrossRef]

26. Zhang, R.; Khalizov, A.; Wang, L.; Hu, M.; Xu, W. Nucleation and growth of nanoparticles in the atmosphere. Chem. Rev. 2011, 112, 1957-2011. [CrossRef] [PubMed]

27. Zoroddu, M.; Medici, S.; Ledda, A.; Nurchi, V.M.; Lachowicz, J.I.; Peana, M. Toxicity of nanoparticles. Curr. Med. Chem. 2014, 21, 3837-3853. [CrossRef] [PubMed]

28. Knol, A.B.; De Hartog, J.J.; Boogaard, H.; Slottje, P.; Van Der Sluijs, J.P.; Lebret, E.; Cassee, F.R.; Wardekker, J.A.; Ayres, J.G.; Borm, P.J.; et al. Expert elicitation on ultrafine particles: Likelihood of health effects and causal pathways. Part. Fibre Toxicol. 2009, 6, 19. [CrossRef] [PubMed]

29. de Prado-Bert, P.; Mercader, E.M.H.; Pujol, J.; Sunyer, J.; Mortamais, M. The effects of air pollution on the brain: A review of studies interfacing environmental epidemiology and neuroimaging. Curr. Environ. Health Rep. 2018, 5, 351-364. [CrossRef] [PubMed]

30. Kittelson, D.B. Engines and nanoparticles: A review. J. Aerosol Sci. 1998, 29, 575-588. [CrossRef]

31. Diaz, E.; Mariën, K.; Manahan, L.; Fox, J. Summary of Health Research on Ultrafine Particles. DOH 334-454; Washington State Department of Health: Tumwater, WA, USA, 2019. 
32. Ohlwein, S.; Kappeler, R.; Joss, M.K.; Künzli, N.; Hoffmann, B. Health effects of ultrafine particles: A systematic literature review update of epidemiological evidence. Int. J. Public Health 2019, 64, 547-559. [CrossRef]

33. Downward, G.S.; Van Nunen, E.J.; Kerckhoffs, J.; Vineis, P.; Brunekreef, B.; Boer, J.M.; Messier, K.P.; Roy, A.; Verschuren, W.M.M.; Van Der Schouw, Y.T.; et al. Long-term exposure to ultrafine particles and incidence of cardiovascular and cerebrovascular disease in a prospective study of a dutch cohort. Environ. Health Perspect. 2018, 126, 127007. [CrossRef]

34. Atkinson, R.W.; Mills, I.C.; Walton, H.; Anderson, H.R. Fine particle components and health-A systematic review and metaanalysis of epidemiological time series studies of daily mortality and hospital admissions. J. Expo. Sci. Environ. Epidemiol. 2015, 25, 208-214. [CrossRef]

35. HEI. Review Panel on Ultrafine Particles. Understanding the Health Effects of Ambient Ultrafine Particles. HEI Perspectives 3; Health Effects Institute: Boston, MA, USA, 2013.

36. Ibald-Mulli, A.; Wichmann, H.-E.; Kreyling, W.; Peters, A. Epidemiological evidence on health effects of ultrafine particles. J. Aerosol Med. 2002, 15, 189-201. [CrossRef]

37. Reche, C.; Viana, M.; Rivas, I.; Bouso, L.; Àlvarez-Pedrerol, M.; Alastuey, A.; Sunyer, J.; Querol, X. Outdoor and indoor UFP in primary schools across Barcelona. Sci. Total Environ. 2014, 493, 943-953. [CrossRef]

38. Lv, Y.; Wang, H.; Wei, S.; Zhang, L.; Zhao, Q. The Correlation between indoor and outdoor particulate matter of different building types in daqing, china. Procedia Eng. 2017, 205, 360-367. [CrossRef]

39. Portela, N.B.; Teixeira, E.C.; Agudelo-Castañeda, D.M.; Civeira, M.D.S.; Silva, L.F.O.; Vigo, A.; Kumar, P. Indoor-outdoor relationships of airborne nanoparticles, BC and VOCs at rural and urban preschools. Environ. Pollut. 2021, $268,115751$. [CrossRef] [PubMed]

40. Fuller, C.H.; Brugge, D.; Williams, P.L.; Mittleman, M.A.; Lane, K.; Durant, J.L.; Spengler, J.D. Indoor and outdoor measurements of particle number concentration in near-highway homes. J. Expo. Sci. Environ. Epidemiol. 2013, 23, 506-512. [CrossRef] [PubMed]

41. Statista. Total Number of People Employed in Offices in Germany from 2016 to 2020. Available online: https: / / www.statista. com/statistics/1022874/number-of-individuals-employed-in-offices-in-germany/ (accessed on 6 August 2021).

42. Eurostat. Sit at Work? You Are One of 39\%. Available online: https:/ / ec.europa.eu/eurostat/web/products-eurostat-news/- / DDN-20190305-1 (accessed on 6 August 2021).

43. Forsberg, H. Videoanalys NUS Området, Passerande Flöde för Fordonstrafik Samt för Övergångställe; Trafikia AB: Uppsala, Sweden, 2014.

44. Chen, B.T.; Schwegler-Berry, D.; Cumpston, A.; Cumpston, J.; Friend, S.; Stone, S.; Keane, M. Performance of a scanning mobility particle sizer in measuring diverse types of airborne nanoparticles: Multi-walled carbon nanotubes, welding fumes, and titanium dioxide spray. J. Occup. Environ. Hyg. 2016, 13, 501-518. [CrossRef]

45. Fierz, M.; Houle, C.; Steigmeier, P.; Burtscher, H. Design, Calibration, and Field Performance of a Miniature Diffusion Size Classifier. Aerosol Sci. Technol. 2011, 45, 1-10. [CrossRef]

46. Ahlvik, P.; DISCmini and Grimm Inc., Stockholm, Sweden. Personal communication, 2021.

47. Vert, C.; Meliefste, K.; Hoek, G. Outdoor ultrafine particle concentrations in front of fast food restaurants. J. Expo. Sci. Environ. Epidemiol. 2015, 26, 35-41. [CrossRef]

48. Hong, K.Y.; Pinheiro, P.O.; Weichenthal, S. Predicting outdoor ultrafine particle number concentrations, particle size, and noise using street-level images and audio data. Environ. Int. 2020, 144, 106044. [CrossRef]

49. Meier, R.; Clark, K.; Riediker, M. Comparative testing of a miniature diffusion size classifier to assess airborne ultrafine particles under field conditions. Aerosol Sci. Technol. 2013, 47, 22-28. [CrossRef]

50. Ferrero, L.; Cappelletti, D.; Busetto, M.; Mazzola, M.; Lupi, A.; Lanconelli, C.; Becagli, S.; Traversi, R.; Caiazzo, L.; Giardi, F.; et al. Vertical profiles of aerosol and black carbon in the Arctic: A seasonal phenomenology along 2 years (2011-2012) of field campaigns. Atmos. Chem. Phys. Discuss. 2016, 16, 12601-12629. [CrossRef]

51. IBM. IBM SPSS Statistics for Windows; Version 26.0; IBM Corp: Armonk, NY, USA, 2019.

52. Isaxon, C.; Gudmundsson, A.; Nordin, E.; Lönnblad, L.; Dahl, A.; Wieslander, G.; Bohgard, M.; Wierzbicka, A. Contribution of indoor-generated particles to residential exposure. Atmos. Environ. 2015, 106, 458-466. [CrossRef]

53. Franco, J.F.; Rojas, N.Y.; Sarmiento, O.L.; Behrentz, E. Urban air pollution in school-related microenvironments in Bogota, Colombia. Ing. Investig. 2013, 33, 42-48. [CrossRef]

54. Kukkonen, J.; López-Aparicio, S.; Segersson, D.; Geels, C.; Kangas, L.; Kauhaniemi, M.; Maragkidou, A.; Jensen, A.; Assmuth, T.; Karppinen, A.; et al. The influence of residential wood combustion on the concentrations of PM2.5 in four Nordic cities. Atmos. Chem. Phys. Discuss. 2020, 20, 4333-4365. [CrossRef]

55. Morawska, L.; Ayoko, G.; Bae, G.; Buonanno, G.; Chao, Y.H.C.; Clifford, S.; Fu, S.C.; Hänninen, O.; He, C.; Isaxon, C.; et al. Airborne particles in indoor environment of homes, schools, offices and aged care facilities: The main routes of exposure. Environ. Int. 2017, 108, 75-83. [CrossRef] [PubMed]

56. Madureira, J.; Slezakova, K.; Costa, C.; Pereira, M.C.; Teixeira, J.P. Assessment of indoor air exposure among newborns and their mothers: Levels and sources of PM10, PM2.5 and ultrafine particles at 65 home environments. Environ. Pollut. 2020, 264, 114746. [CrossRef] [PubMed]

57. Chen, C.; Yao, M.; Luo, X.; Zhu, Y.; Liu, Z.; Zhuo, H.; Zhao, B. Outdoor-to-indoor transport of ultrafine particles: Measurement and model development of infiltration factor. Environ. Pollut. 2020, 267, 115402. [CrossRef] 
58. Kumar, P.; Ketzel, M.; Vardoulakis, S.; Pirjola, L.; Britter, R. Dynamics and dispersion modelling of nanoparticles from road traffic in the urban atmospheric environment-A review. J. Aerosol Sci. 2011, 42, 580-603. [CrossRef]

59. Holøs, S.B.; Yang, A.; Lind, M.; Thunshelle, K.; Schild, P.; Mysen, M. VOC emission rates in newly built and renovated buildings, and the influence of ventilation-A review and meta-analysis. Int. J. Vent. 2018, 18, 153-166. [CrossRef]

60. Nørgaard, A.; Kudal, J.; Kofoed-Sørensen, V.; Koponen, I.; Wolkoff, P. Ozone-initiated VOC and particle emissions from a cleaning agent and an air freshener: Risk assessment of acute airway effects. Environ. Int. 2014, 68, 209-218. [CrossRef]

61. Kim, K.-H.; Kabir, E.; Jahan, S.A. Airborne bioaerosols and their impact on human health. J. Environ. Sci. 2018, 67, 23-35. [CrossRef] [PubMed]

62. Shi, X.; Chen, R.; Huo, L.; Zhao, L.; Bai, R.; Long, D.; Pui, D.Y.H.; Rang, W.; Chen, C.; Xiaofei, S.; et al. Evaluation of nanoparticles emitted from printers in a lean chamber, a copy center and office rooms: Health risks of indoor air quality. J. Nanosci. Nanotechnol. 2015, 15, 9554-9564. [CrossRef] [PubMed]

63. Kwon, H.-S.; Ryu, M.H.; Carlsten, C. Ultrafine particles: Unique physicochemical properties relevant to health and disease. Exp. Mol. Med. 2020, 52, 318-328. [CrossRef] [PubMed]

64. Zhao, J.; Birmili, W.; Wehner, B.; Daniels, A.; Weinhold, K.; Wang, L.; Merkel, M.; Kecorius, S.; Tuch, T.; Franck, U.; et al. Particle mass concentrations and number size distributions in 40 homes in germany: Indoor-to-outdoor relationships, diurnal and seasonal variation. Aerosol Air Qual. Res. 2020, 20, 576-589. [CrossRef]

65. Kumar, P.; Morawska, L.; Birmili, W.; Paasonen, P.; Hu, M.; Kulmala, M.; Harrison, R.M.; Norford, L.; Britter, R. Ultrafine particles in cities. Environ. Int. 2014, 66, 1-10. [CrossRef]

66. Olivares, G.; Johansson, C.; Ström, J.; Hansson, H.-C. The role of ambient temperature for particle number concentrations in a street canyon. Atmos. Environ. 2007, 41, 2145-2155. [CrossRef]

67. Mandin, C.; Trantallidi, M.; Cattaneo, A.; Canha, N.; Mihucz, V.G.; Szigeti, T.; Mabilia, R.; Perreca, E.; Spinazzè, A.; Fossati, S.; et al. Assessment of indoor air quality in office buildings across Europe-The OFFICAIR study. Sci. Total Environ. 2017, 579, 169-178. [CrossRef]

68. Giemsa, E.; Soentgen, J.; Kusch, T.; Beck, C.; Münkel, C.; Cyrys, J.; Pitz, M. Influence of local sources and meteorological parameters on the spatial and temporal distribution of ultrafine particles in Augsburg, Germany. Front. Environ. Sci. 2021, 8,280 . [CrossRef]

69. Saha, P.K.; Robinson, E.S.; Shah, R.U.; Zimmerman, N.; Apte, J.S.; Robinson, A.L.; Presto, A.A. Reduced ultrafine particle concentration in urban air: Changes in nucleation and anthropogenic emissions. Environ. Sci. Technol. 2018, 52, 6798-6806. [CrossRef] [PubMed]

70. Olstrup, H.; Johansson, C.; Forsberg, B.; Åström, C. Association between mortality and short-term exposure to particles, ozone and nitrogen dioxide in Stockholm, Sweden. Int. J. Environ. Res. Public Health 2019, 16, 1028. [CrossRef] [PubMed]

71. Gidhagen, L.; Johansson, C.; Langner, J.; Foltescu, V. Urban scale modeling of particle number concentration in Stockholm. Atmos. Environ. 2005, 39, 1711-1725. [CrossRef]

72. Karl, M.; Kukkonen, J.; Keuken, M.P.; Lützenkirchen, S.; Pirjola, L.; Hussein, T. Modeling and measurements of urban aerosol processes on the neighborhood scale in Rotterdam, Oslo and Helsinki. Atmos. Chem. Phys. Discuss. 2016, 16, 4817-4835. [CrossRef]

73. Von Barany, D.; Kuhlbusch, T.A.; Monz, C.; Dziurowitz, N.; Pelzer, J.; Vossen, K.; Dietrich, S.; Götz, U.; Kiesling, H.-J.; Asbach, C.; et al. Comparability of portable nanoparticle exposure monitors. Ann. Occup. Hyg. 2012, 56, 606-621. [CrossRef]

74. Asbach, C.; Kaminski, H.; Fissan, H.; Monz, C.; Dahmann, D.; Mülhopt, S.; Paur, H.-R.; Kiesling, H.J.; Herrmann, F.; Voetz, M.; et al. Comparison of four mobility particle sizers with different time resolution for stationary exposure measurements. J. Nanoparticle Res. 2009, 11, 1593-1609. [CrossRef]

75. Ozgen, S.; Becagli, S.; Bernardoni, V.; Caserini, S.; Caruso, D.; Corbella, L.; Dell'Acqua, M.; Fermo, P.; Gonzalez, R.; Lonati, G.; et al. Analysis of the chemical composition of ultrafine particles from two domestic solid biomass fired room heaters under simulated real-world use. Atmos. Environ. 2017, 150, 87-97. [CrossRef]

76. Corsini, E.; Vecchi, R.; Marabini, L.; Fermo, P.; Becagli, S.; Bernardoni, V.; Caruso, D.; Corbella, L.; Dell'Acqua, M.; Galli, C.L.; et al. The chemical composition of ultrafine particles and associated biological effects at an alpine town impacted by wood burning. Sci. Total Environ. 2017, 587-588, 223-231. [CrossRef]

77. Li, X.; Li, Y.; Lawler, M.J.; Hao, J.; Smith, J.N.; Jiang, J. Composition of ultrafine particles in urban beijing: Measurement using a thermal desorption chemical ionization mass spectrometer. Environ. Sci. Technol. 2021, 55, 2859-2868. [CrossRef] [PubMed]

78. Pedata, P.; Stoeger, T.; Zimmermann, R.; Peters, A.; Oberdörster, G.; D'Anna, A. Are we forgetting the smallest, sub $10 \mathrm{~nm}$ combustion generated particles? Part Fibre Toxicol. 2015, 12, 1-4. [CrossRef] [PubMed]

79. Sirignano, M.; Conturso, M.; Magno, A.; Di Iorio, S.; Mancaruso, E.; Vaglieco, B.M.; D'Anna, A. Evidence of sub-10 nm particles emitted from a small-size diesel engine. Exp. Therm. Fluid Sci. 2018, 95, 60-64. [CrossRef]

80. Nosko, O.; Vanhanen, J.; Olofsson, U. Emission of 1.3-10 nm airborne particles from brake materials. Aerosol Sci. Technol. 2016, 51, 91-96. [CrossRef]

81. Johnson, A.R. Laser and 3-Dimensional Printers: Characterizing Emissions and Occupational Exposures; West Virginia University: Morgantown, WV, USA, 2018.

82. Weldon, B.A.; Faustman, E.M.; Oberdörster, G.; Workman, T.; Griffith, W.C.; Kneuer, C.; Yu, I.J. Occupational exposure limit for silver nanoparticles: Considerations on the derivation of a general health-based value. Nanotoxicology 2016, 10, 945-956. [CrossRef] [PubMed] 
83. OSHA. Occupational Safety and Health Administration. Working Safely with Nanomaterials; Occupational Safety and Health Administration: Washington, DC, USA, 2013.

84. Schulte, P.A.; Murashov, V.; Zumwalde, R.; Kuempel, E.D.; Geraci, C.L. Occupational exposure limits for nanomaterials: State of the art. J. Nanoparticle Res. 2010, 12, 1971-1987. [CrossRef]

85. Van Veelen, W.; Streekstra, W.-H.; Van Broekhuizen, P.; Schulte, P.; Reijnders, L. Exposure limits for nanoparticles: Report of an international workshop on nano reference values. Ann. Occup. Hyg. 2012, 56, 515-524. [CrossRef]

86. Broekhuizen, P.; Hendrikx, B. Nano reference values in the Netherlands. Gefahrst. Reinhalt. Luft 2013, 73, 407-414.

87. Wientzek, S. Emission Test of a XEROX Everyday Imitation Toner Cartridge on HP Printer; Fraunhofer Wil-helm-Klauditz-Institute: Braunschweig, Germany, 2020. 